\title{
Udenlandske skønlitterære klassikere på dansk 1967-99. Træk af en udgivelseshistorie
}

\section{Af Rune Eriksson}

\section{Forestillingen om klassikerne}

Den litterære klassiker er ikke død. Klassikerne er tilbagevendende referencepunkter i anmeldelser, de er emne for en stor del af artiklerne i de litterære tidsskrifter, og i de litterære monografier er klassikerne noget nær enerådende. På internettet er mængden, omfanget og kvaliteten af klassikersites konstant i vækst, og klassikerne bliver jævnligt filmatiseret og dramatiseret. Men bliver de også læst? Og i givet fald hvor meget? Og er det de samme klassikere, der læses år efter år? Dette, og især det sidste, er spørgsmål, som denne artikel beskæftiger sig med.

Umiddelbart kan den litterære kanon forekomme stabil på grænsen til det statiske, og den mest hårdnakkede forestilling om klassikerne er da også, at de er tidløse. Således karakteriserer Den Store Danske Encyklopaedi en klassiker som "en skribent, kunstner eller værk med varig anseelse", hvad der måske lyder tilforladeligt, men definitionen tager ikke højde for, at anseelse ingenlunde er en absolut størrelse. Fx nyder en forfatter som Henrik Pontoppidan stor anseelse herhjemme, men selv om han modtog Nobelprisen i 1917, er han i dag ikke som et stort navn uden for Danmark og slet ikke uden for Europa (1).

I sjældne tilfælde kan det noesten se ud, som om en forfatter eller et værk ganske ubesværet krydser tid og rum - H. C. Andersen er et godt eksempel men ingen forfatter og intet værk har stået lige centralt alle steder og til hver en tid. Det betyder ikke, at klassikerne er som alle andre forfattere og bøger, for det store flertal af disse synker ganske anderledes kvikt mod glemslens dyb. Men også klassikerne relativeres af tid og rum, og det bør en unders $\emptyset$ gelse af deres gennemslagskraft og status - som er emnet her - ikke ignorere.

\section{Metode og afgrænsninger}

En sådan undersøgelse kan gribes an på forskellig vis. Man kan diskutere klassikernes betydning for senere forfattere, man kan analysere omfanget og karakteren af den mere 'officielle' reception i fx litteraturhistorier, eller man kan unders $\emptyset$ ge den mere folkelige gennemslagskraft via interviews, udlåns- eller bogsalgsstatistikker. Egentlig ville jeg helst have studeret selve salget af klassikerne, men desværre informerer de danske forlag kun sjældent om dette, og i øvrigt kan oplysningerne være gået tabt, hvorfor valget i stedet er faldet på den metode, der ligner mest: En udgivelseshistorie. En sådan kan ganske vist ikke uden videre 'oversættes' til faktisk gennemslagskraft, da oplagsstørrelse og salg af forskellige titler og udgaver selvsagt kan svinge betragteligt, men det må dog antages, at når en bog trykkes igen og igen, er det fordi ældre udgaver har solgt godt, og at mange værdsætter titlen. Som sådan indeholder en udgi- 
velseshistorie et element af reception - nemlig de almindelige læseres.

Klassikermarkedet er i Danmark groft sagt todelt, idet de danske klassikere i betydeligt omfang indgår i bl.a. danskundervisningen, hvorfor der af nogle titler vil være et stort salg til undervisningssektoren, mens de udenlandske klassikere stort set må overleve gennem salg til private og biblioteker. For ikke at blande disse to 'kulturer' sammen, har jeg valgt udelukkende at koncentrere mig om de skønlitterære udenlandske klassikere (for voksne), og forfattergrundlaget udg øres af de ca. 2200 forfattere, der har eget opslag i mindst ét af de to nyere danske forfatterleksika om udenlandske forfattere: Rosinantes Forfatterleksikon. Udenlandsk litteratur og Gads udenlandske forfatterleksikon (2). Unders $\emptyset$ gelsesperioden er fastsat til 1967-99, altså sidste tredjedel af det 20. århundrede, og for at indgå i unders $\varnothing$ gelsen skal et værk have været udgivet på originalsproget senest 1945 . Dette er de fundamentale afgrænsninger, men en sådan undersøgelse lader sig ikke realisere, medmindre der træffes en lang række andre valg (3).
Verificeringen af udgivelserne er primært sket gennem DanBib og Dansk Bogfortegnelse, men også andre kilder er benyttet.

Og nu til resultaterne, som de foreligger, når den primære opgave ikke er at gøre rede for udviklingen for de enkelte forfattere og værker, men studere de overordnede bevægelser på klassikermarkedet via følgende mere (litteratur)sociologiske kategorier: Bindudvikling og forfatterpopulation, klassikernes fordeling på køn og genrer, samt deres tidslige og geografiske oprindelse. Endelig vil resultaternes relevans for bibliotekerne kort blive diskuteret.

\section{Bindudvikling og forfatterpopulation}

Mark Twain har hævdet, at klassikere er "books people praise and don't read" (4). Men medmindre forlagene udgiver bøger, som ikke bliver solgt - eller i hvert fald ikke læst - passer definitionen ikke på er det moderne Danmark, da der fra 1967. 99 er udgivet 2596 bind med udenlandske klassikere på dansk. Det er i gennemsnit 78,6 bind om

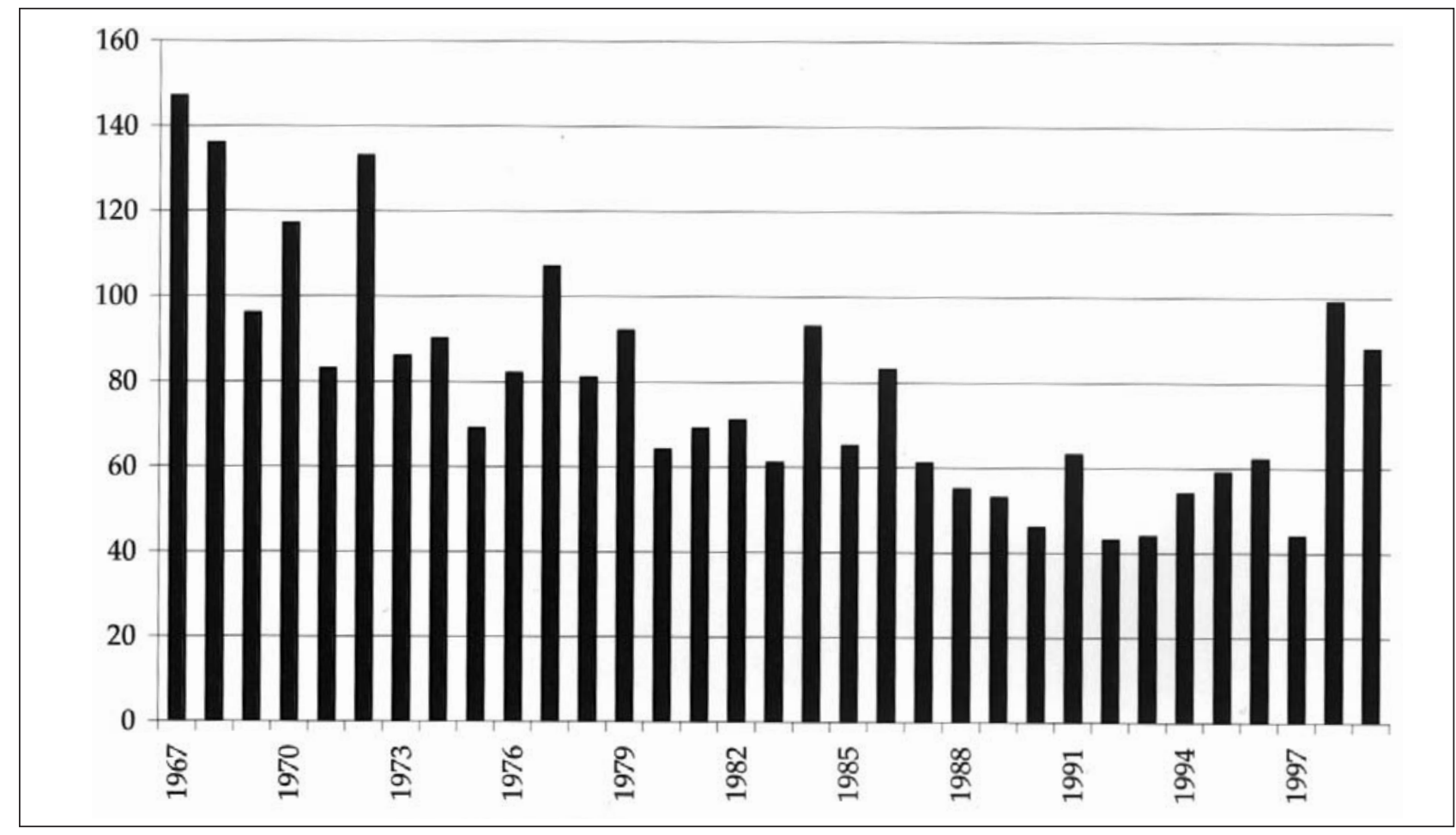

Figur 1: Udenlandske klassikere på dansk. Antal bind 1967-99. 
året, men som det fremgår af Figur 1, er der store udsving - med 147 bind i 1967 og 43 bind i 1992 som yderpunkter. Overordnet er kurven dog stærkt faldende, hvad der tydeligt fremgår, når man deler unders $\varnothing$ gelsesperiodens 33 år op i tre elleveårsperioder, hvor det enkelte års mere eller mindre vilkårlige bindantal stort set er elimineret (Tabel 1).

\begin{tabular}{|l|c|c|}
\hline Periode & Bind & Gennemsnit pr. år \\
\hline $1967-77$ & 1146 & 104,1 \\
\hline $1978-88$ & 795 & 72,3 \\
\hline $1989-99$ & 655 & 59,5 \\
\hline
\end{tabular}

Tabel 1: Bindudviklingen i elleveårsperioder

Det alvorligste fald sker i midterperioden, hvor den såkaldte bogkrise indtræder efter årtiers kraftig ekspansion, men nedgangen fortsætter, og totalt daler bindantallet med næsten $43 \%$ fra første til sidste periode. Der kan således næppe være tvivl om, at de udenlandske klassikere (som skønlitteraturen i almindelighed) har haft en vigende gennemslagskraft gennem det 20. århundredes sidste årtier, men det er dog muligt at anskue tilbagegangen fra forskellige vinkler.

For det første bevirker fastsættelsen af 1945 som klassikerkriterium, at bøgerne har skullet overleve stadig længere for overhovedet at kunne indgå i undersøgelsen. I 1967 skulle den udenlandske originaludgave kun have mindst 22 år på bagen, mens alderskravet var steget til 54 år i 1999, og de årlige bindantal ville utvivlsomt have været mere jævnbyrdige, hvis der frem for et bestemt årstal var blevet fastlagt en bestemt alder, fx 25 år (5). For det andet er 1967 selve kulminationsåret for billigbøgerne, mens 1970'erne er bogklubbernes storhedstid (6), og begge dele var til uhyre stor gavn for udbredelsen af de udenlandske klassikere. Perioden fra 1967-77 er altså temmelig enestående, og det kan ikke udelukkes, at klassikerne klarede sig bedre i 1980'erne og 1990'erne end i fx 1950 'erne. Men ifald disse forhold modificerer billedet af tilbagegangen, accentueres krisetegnene af de generelt faldende oplagstal (7), som indikerer, at det faktiske antal klassikereksemplarer er faldet langt mere drastisk end bindantallet. Derfor er der også ekstra grund til at glæde sig over, at klassikerne synes at have fået en voldsom renæssance sidst i unders $\emptyset$ gelsesperioden. Således er 1998 - hvor bindantallet, helt ekstraordinært, steg med $125 \%$ i forhold til året før - det bedste klassikerår siden 1977, og 1999 er ikke meget ringere, men om denne bølge er fortsat ind i det nye århundrede ligger uden for unders $\varnothing$ gelsens rammer.

Imidlertid fortæller bindudviklingen ikke, om klassikerne i den første periode blot efterhånden er udkommet sjoeldnere, eller om bestemte titler eller hele forfatterskaber er forsvundet fra det danske bogmarked. Hvis de samme forfattere og titler blot er blevet udgivet sjældnere, har gennemslagskraften selvfølgelig været dalende, men klassikerne er alligevel grundlæggende forblevet en stabil størrelse. Derimod er de dynamiske, hvis forfattere eller titler er gledet ud af markedet, eller nye er kommet til. Begge dele gør sig gældende. Hvis vi koncentrerer os om forfatterne (og ser bort fra de enkelte værker), er 239 forfattere repræsenteret fra 1967-77, mens 173 er repræsenteret fra 1989-99 - men heraf er kun 106 gengangere! Det vil sige, at 133 ikke er blevet genudgivet, hvorimod 67 nye er kommet til. Af disse er 41 dog ikke egentlige nyheder, da de også er blevet udgivet $f \varnothing r$ 1967, men 26 er genuint nye klassikere på dansk. Klassikerne er altså ikke noget, der ukritisk videreføres fra den ene generation til den næste.

\section{Mandlige og kvindelige klassikere}

Undersøgelsesperioden fra 1967 til 1999 er en periode, hvor $k \phi n$ nærmest konstant var på dagsordenen, og især 1970'erne er kendt som kvindebevægelsens storhedstid. Senere, i 1991, argumenterede amerikaneren Susan Faludi dog for, at det igen var gået tilbage med ligestillingen (8), i hvert fald i USA, men gennem hele perioden har kønsproblematikken aldrig været længere væk end tæt på, og eksempelvis inden for litteraturvidenskaben er der for længst etableret en feministisk retning - nogle vil sige flere.

Men har bemeldte kønsdebat betydet noget for udgivelsen af klassikere? Som det fremgår af Figur 2, synes det afgjort at være tilfældet: Med 132 bind topper mændene allerede i unders $\varnothing g e l-$ sens første år, 1967, hvorimod kvinderne, med 26 


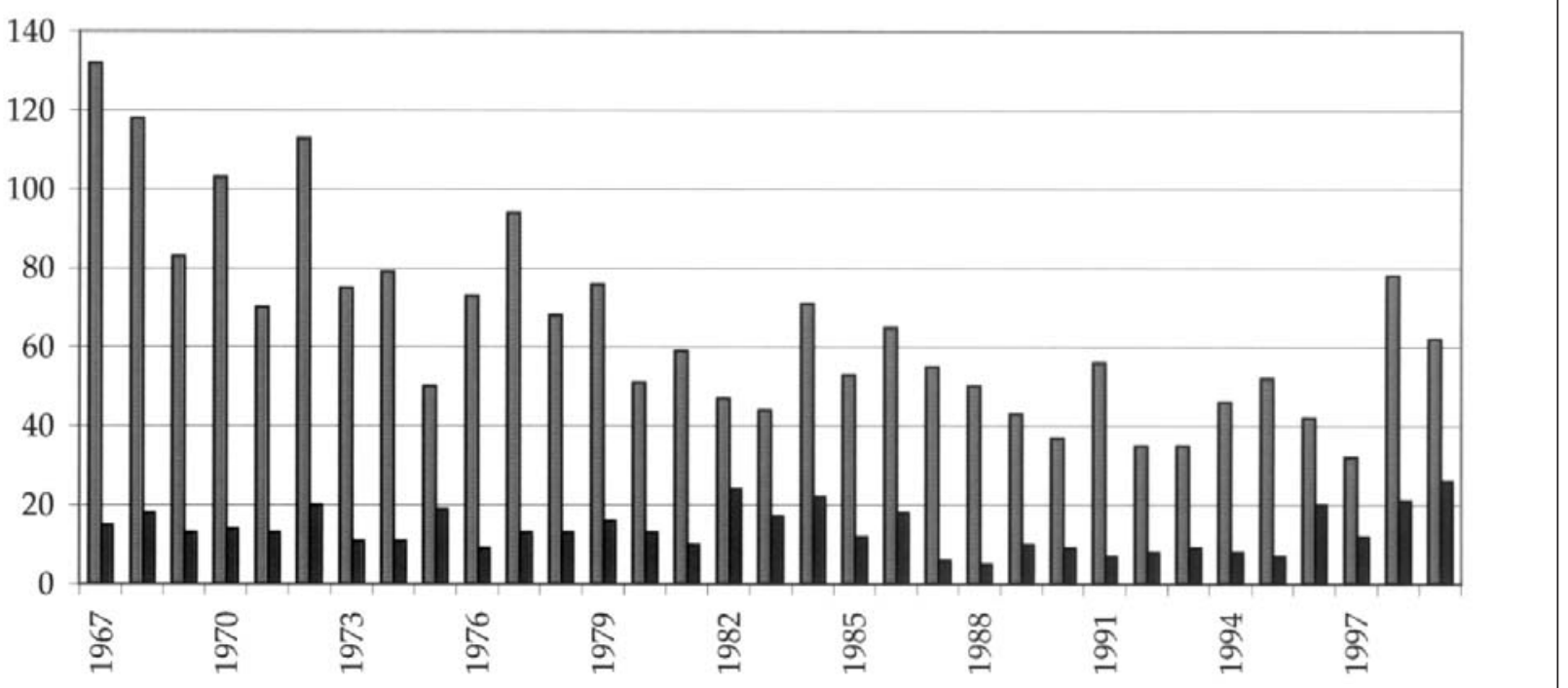

Figur 2: Udenlandske klassikere på dansk: Antal bind fordelt på mandlige og kvindelige forfattere.

bind, først kulminerer i det sidste, 1999! Det omvendte gælder dog ikke. Mændene når bunden i 1997 (32 bind) og får derefter stor fremgang, mens kvindernes svageste år er 1988 (fem bind). De væsentligste pointer - at der udgives langt flere bind af mænd end af kvinder hvert eneste år, men at mændene topper i begyndelse, og at kvinderne står relativt stærkt mod slutningen - bekræftes dog, hvis man ser på henholdsvis det totale antal bind og den procentuelle fordeling for de to $\mathrm{k} \emptyset \mathrm{n}$ i hver af de tre elleveårsperioder (Tabel 2).

\begin{tabular}{|l|c|c|c|c|}
\hline Periode & Bind & & $\%$ & \\
\hline & Mænd & Kvinder & Mænd & Kvinder \\
\hline $1967-77$ & 989 & 156 & 86,4 & 13,6 \\
\hline $1978-88$ & 639 & 156 & 80,4 & 19,6 \\
\hline $1989-99$ & 518 & 137 & 79,1 & 20,9 \\
\hline I alt & 2146 & 449 & 82,7 & 17,3 \\
\hline
\end{tabular}

Tabel 2: Bindudviklingen for mond og kvinder $i$ elleveårsperioder

Bindantallet for mændene er næsten halveret undervejs, mens kvinderne er sluppet med en mindre tilbagegang i den sidste periode, hvorfor deres andel af klassikermarkedet er vokset betragteligt.
Igen er den største forskydning dog sket i midterperioden, hvad der kan synes overraskende, da kvindebevægelsens storhedstid som nævnt henregnes til 1970'erne, mens mellemperioden, der stort set er synonym med 1980'erne, almindeligvis betragtes som en konservativ epoke. Men det år, hvor kønnene har den forholdsvis mest ligelige fordeling, er 1982, hvor kvinderne for første og eneste gang står bag ca. hvert tredje bind - $24 \mathrm{ud}$ af 81. Også fra 1996-99 er kvinderne godt repræsenteret, men hvor 1982 er præget af mange kvindelige forfattere og herunder en del kvindesagskvinder, skyldes de pæne tal fra 1996-99 primært en massiv relancering af Agatha Christie, som står for ikke mindre end 33 af de 79 kvindebind, så en feministisk eller kvindepolitisk renæssance kan man vanskeligt tale om.

\section{Klassikernes tidsmassige oprindelse}

Som tidligere nævnt skulle en bog i 1967 kun være mindst 22 år gammel, hvorimod den skulle være mindst 54 år i 1999. På den baggrund kunne det tænkes, at den generelle nedgang især har ramt de nyere klassikere, da tyve eller tredive år kan tage temmelig hårdt på en bog fra fx mellemkrigstiden, mens ældre værker, fx fra oldtiden, jo for længst 


\begin{tabular}{|l|c|r|r|r|r|r|r|r|}
\hline Oprindelse & \multicolumn{2}{|l|}{ Bind } & \multicolumn{1}{l|}{$\%$} \\
\hline & $1967-77$ & $1978-88$ & $1989-99$ & I alt & $1967-77$ & $1978-88$ & $1989-99$ & I alt \\
\hline Oldtiden & 52 & 55 & 47 & 154 & 4,5 & 6,9 & 7,2 & 5,9 \\
\hline Middelalderen & 1 & 2 & 5 & 8 & 0,1 & 0,3 & 0,8 & 0,3 \\
\hline $1300-1499$ & 10 & 3 & 1 & 14 & 0,9 & 0,4 & 0,2 & 0,5 \\
\hline $1500-1699$ & 56 & 39 & 12 & 107 & 4,9 & 4,9 & 1,8 & 4,1 \\
\hline $1700-1799$ & 30 & 15 & 13 & 58 & 2,6 & 1,9 & 2,0 & 2,2 \\
\hline $1800-1849$ & 89 & 63 & 56 & 208 & 7,8 & 7,9 & 8,5 & 8,0 \\
\hline $1850-1899$ & 194 & 135 & 109 & 438 & 16,9 & 17,0 & 16,6 & 16,9 \\
\hline $1900-1945$ & 714 & 483 & 412 & 1609 & 62,3 & 60,8 & 62,9 & 62,0 \\
\hline I alt & 1146 & 795 & 654 & 2596 & 100,0 & 100,1 & 100,0 & 99,9 \\
\hline
\end{tabular}

Tabel 3: Klassikernes tidsmassige oprindelse i elleveårsperioder og $i$ alt

har bevist deres levedygtighed. Dette synes imidlertid ikke at være tilfældet, som det fremgår af Tabel 3, der viser, hvornår udgivelserne første gang forelå på originalsproget (9). Som også i de efterfølgende tabeller angives tallene både totalt og i elleveårsperioder, og både i antal bind og procentuelt.

Perioderne er udformet, så deres længde aftager op mod nutiden, men alligevel står den nyeste periode, 1900-45, uhyre stærkt, og andelen er snarere blevet styrket end svækket undervejs. 18501899 står markant svagere, men med ca. hvert sjette bind af udgivelserne er det dog klart den næststærkeste periode. Også 1800-49 er solidt og stabilt repræsenteret, og i samtlige elleveårsperioder stammer ca. $88 \%$ af originaludgaverne fra efter 1800, så måske er klassikerne ikke helt så tidløse, som nogen vil gøre dem til.

Ifølge den berømte franske litteraturkritiker Sainte-Beuve taler klassikerne "lige utvungent til alle Tidsaldre" (10), og den danske litteraturkritiker Erik Skyum-Nielsen mener, at "den, der i dag læser bøger med hundrede eller totusind år på bagen, kan opleve dem som fuldkommen samtidige" (11). I så fald bliver skævheden i udgivelsesmønstret imidlertid helt uforståelig, hvorfor man nok snarere $b ø r$ sætte sin lid til Georg Brandes, når han påpeger, at klassikerne jo er "skrevet for en tidligere Slægt og derfor i Reglen [indeholder] noget, der er det opvoksende slægtled fremmed (12)". Og man må gå ud fra, at denne grad af fremmedhed vokser med tiden, hvorfor værket typisk bliver stadigt sværere at forstå og værdsætte, jo længere der er mellem affattelsen og receptionen af det.

Men derudover må der konstateres en forbløffende stabilitet i den procentuelle fordeling for de tre nyeste perioders vedkommende. Som nævnt har der været en ganske betydelig udskiftning i forfatterpopulationen fra første til sidste elleveårsperiode, men fordelingen i bindenes periodemæssige afstamning ligger fast. Man skulle tro, den var vedtaget ved lov!

Men det er den ikke, og faktisk er det før 1800, man finder de virkelige udsving. Bedst har de to ældste epoker klaret sig: Værkerne fra oldtiden (som de gamle grækere i al væsentlighed står for) har i kraft af en stort set stabil udgivelsesfrekvens styrket deres andel af klassikermarkedet, og middelalderen har ligefrem fået femdoblet sit bindantal undervejs, men da tallene er meget små (ét og fem bind) er stigningen mindre signifikant (13). På den anden side er det vel nærliggende, at de senere års stigende interesse for middelalderen som historisk periode kan have påvirket antallet af skønlitterære udgivelser fra samme tid.

Derimod har perioden fra 1300-1499 oplevet et drastisk fald, men også her er tallene så små, at udviklingen ikke skal tolkes for kontant, især ikke da en enkelt bog, Boccaccios Dekameron, ligger til grund for otte af periodens 14 bind. Mere signifikante er tallene tilsyneladende for 1500-1699, som styrtdykker fra 56 til 12 bind undervejs, men i alle 
elleveårsperioderne står der Shakespeare på ca. to tredjedele af bindene, hvorfor også nedturen i meget høj grad handler om ham. Forfatter-sammensætningen er noget mere alsidig for 1700-tallets vedkommende, men med en andel på kun lidt over to procent er interessen for oplysningstidens litteratur såre beskeden, og det er ikke blevet bedre med tiden.

Totalt har det halve årtusind fra 1300-1799 fostret mindre end syv procent af klassikerbindene - eller nogenlunde det samme som fem gennemsnitsår fra 1900-45!

\section{Klassikernes geografiske oprindelse}

Især siden slutningen af 60'erne har Vestens tilbøjelighed til at ignorere andre kulturers litteratur i stigende grad mødt kritik. På amerikanske universiteter har man harceleret over, at kanon næsten udelukkende bestod af dead white men, og krævet fuld anerkendelse af kvinder, diverse mindretal (homoseksuelle, sorte mv.) samt den store verden uden for Vesten. Et fag som Cultural Studies og en litteraturvidenskabelig retning som postkoloniale studier er udmøntninger af denne kritik, og herhjemme proklamerede redaktørerne af Politikens Verdens litteraturhistorie allerede i 1971, at "Den tid bør være forbi, da verdenslitteraturen blot omfattede græske og romerske forfattere, middelalderens skrifter og de europæiske nationallitteraturer. (...) Nærværende værk må da betragtes som et moderne fors $\varnothing \mathrm{g}$ på at skildre den litterære verden som en helhed." (14)

Hans Hertel var dog næppe imponeret over Politikens værk, i hvert fald skærpede han tonen yderligere i Verdens litteraturhistorie fra Gyldendal i
1985: "Da Goethe dannede det [begrebet verdenslitteratur] i 1820'rne betød det den universelle litterære kunst, der holdt, uanset hvor den kom fra. Men i praksis, i opslagsværkerne, er verdenslitteratur blevet = europæisk litteratur, suppleret med symbolske skrabud for den klassisk orientalske tradition og de ikke-europæiske mesterværker der har været så heldige at imødekomme vestlige smagsbegreber og blive indlemmet på kunstkammeret. Siden 1960'erne har mange sat spørgsmålstegn ved denne nedladenhed som udtryk for et eurocentrisk, udemokratisk, forældet verdensbillede, og man har krævet litteraturhistorien åbnet for de undertrykte folkekulturer f.eks. i Latinamerika, Afrika og Østasien.” (15)

Indholdet i dette værk er som lovet mere internationalt end tidligere, men spørgsmålet er om det har nyttet noget. Tabel 4 angiver klassikerudgivelsernes fordeling på verdensdele.

Trods et kraftigt faldende bindantal er den europæiske andel af klassikerudgivelserne steget støt. I den henseende blev eurocentrismen altså ikke svækket men styrket i det 20. århundredes sidste par årtier. Men måske lidt uventet er fremgangen sket på bekostning af Nordamerika, som er synonym med USA, da der ikke er udgivet en eneste klassiker fra Canada. Derimod har Latinamerika haft fremgang, men tallene er fortfarende meget små, og set i lyset af den internationale litterære opmærksomhed, som verdensdelen har fået, siden Gabriel García Márquez i 1967 udgav Hundrede års ensomhed (dansk udg. 1969), er resultatet lidet imponerende. Klassikere fra Asien, som ellers har en lang litterær tradition, er der år imellem, og da klassikere fra Afrika nærmest ikke findes på dansk, er resultatet, at over $98 \%$ af klassikerne

\begin{tabular}{|l|r|r|r|r|r|r|r|r|}
\hline Verdensdel & \multicolumn{3}{l|}{ Bind } & \multicolumn{1}{l|}{$\%$} & \multicolumn{1}{l|}{} \\
\hline & $1967-77$ & $1978-88$ & $1989-99$ & I alt & $1967-77$ & $1978-88$ & $1989-99$ & I alt \\
\hline Europa & 953 & 676 & 566 & 2195 & 83,1 & 85,0 & 86,4 & 84,6 \\
\hline Nordamerika & 187 & 105 & 78 & 370 & 16,3 & 13,2 & 11,9 & 14,3 \\
\hline Latinamerika & 4 & 9 & 9 & 22 & 0,3 & 1,1 & 1,4 & 0,8 \\
\hline Asien & 2 & 4 & 2 & 8 & 0,2 & 0,5 & 0,3 & 0,3 \\
\hline Afrika & 0 & 1 & 0 & 1 & 0,0 & 0,1 & 0,0 & 0,0 \\
\hline I alt & 1146 & 795 & 655 & 2596 & 100,0 & 99,9 & 100,0 & 100,0 \\
\hline
\end{tabular}

Tabel 4: Klassikernes geografiske oprindelse i elleveårsperioder og $i$ alt 


\begin{tabular}{|l|r|r|r|r|r|r|r|c|}
\hline & \multicolumn{1}{|l}{ Bind } & \multicolumn{2}{l|}{$\%$} \\
\hline & $1967-77$ & $1978-88$ & $1989-99$ & I alt & $1967-77$ & $1978-88$ & $1989-99$ & I alt \\
\hline Storbritannien & 323 & 236 & 170 & 729 & 28,2 & 29,7 & 26,0 & 28,1 \\
\hline Frankrig & 127 & 82 & 92 & 301 & 11,1 & 10,3 & 14,0 & 11,6 \\
\hline Norge & 95 & 66 & 24 & 185 & 8,3 & 8,3 & 3,7 & 7,1 \\
\hline Rusland & 81 & 47 & 49 & 177 & 7,1 & 5,9 & 7,5 & 6,8 \\
\hline Sverige & 59 & 66 & 28 & 153 & 5,2 & 8,3 & 4,3 & 5,9 \\
\hline Tyskland & 54 & 50 & 46 & 150 & 4,7 & 6,3 & 7,0 & 5,8 \\
\hline Oldt. Græken. & 47 & 50 & 40 & 137 & 4,1 & 6,3 & 6,1 & 5,3 \\
\hline Sydeuropa & 28 & 18 & 25 & 71 & 2,4 & 2,3 & 3,8 & 2,7 \\
\hline Østeuropa & 28 & 19 & 29 & 76 & 2,4 & 2,4 & 4,3 & 2,9 \\
\hline
\end{tabular}

Tabel 5: Reprasentationen af udvalgte europaiske lande og regioner i elleveårsperioder og $i$ alt

stammer fra Europa eller USA i samtlige perioder.

At Europa har styrket sin position betyder imidlertid ikke, at alle lande og områder har klaret sig lige godt gennem hele unders $\emptyset$ gelsesperioden, og Tabel 5 viser udviklingen. Kategorierne er de syv lande (herunder oldtidens Grækenland), der er repræsenteret med mere end 100 bind, samt regionerne Østeuropa (minus Rusland) og Sydeuropa (Spanien, Portugal, Italien og det moderne Grækenland) (16). Procentsatserne henviser til landenes andel af det totale antal klassikerudgivelser, ikke kun de europæiske.

Storbritannien er i særklasse. Undersøgelsens to bedst repræsenterede forfattere - Agatha Christie og Shakespeare! - kommer herfra, men ikke mindre end 69 britiske forfattere er blevet udgivet i unders $\varnothing$ gelsesperioden. Frankrig er hver gang nummer to og har en bemærkelsesværdig fremgang i den sidste periode, hvor landet faktisk også har passeret USA (jvf. Tabel 4). Rusland har en ret stabil andel på ca. syv procent, og Tyskland er kommet op på samme niveau. De gamle grækere har særegne afsætningsmuligheder, da der skal leveres bøger til undervisningen i oldtidskundskab i gymnasiet, og antagelig er det derfor, de har kunnet fastholde et stort set stabilt bindantal og har opnået en relativ styrkelse på klassikermarkedet. Derimod er både Norge og Sverige styrtdykket i sidste periode, og hvor hvert sjette bind kom fra Skandinavien fra 1978-88, er det næsten kun hvert trettende fra 1989-99.
I modsætning hertil har Østeuropa og Sydeuropa klaret sig godt i den sidste periode. De to områders repræsentation på dansk løber næsten parallelt: 28 bind hver fra 1967-77, et typisk fald fra 1978-88, hvorpå en pæn stigning i bindantallet udløser en markant procentuel fremgang fra 198999. Hermed har østeuropæerne overhalet Sverige på det danske marked, sydeuropæerne følger lige efter, og begge områder har passeret Norge. Derimod var både Norge og Sverige næsten fire gange så stærkt repræsenteret som Østeuropa henholdsvis Sydeuropa i mellemperioden!

Alt i alt kan det således konkluderes, at danskernes smag synes at være blevet mindre skandinavisk, mindre amerikansk og mere europæisk gennem undersøgelsesperioden. Om det har noget med Danmarks medlemskab af EU at gøre skal være usagt. Og så er vi tilsyneladende også blevet lidt mere modtagelige for latinamerikanske klassikere, men et egentligt gennembrud for fjerne kulturers klassikere er der på ingen måde tale om. I litteraturens verden har det for alle andre end europæere og amerikanere altid været svært at krydse den danske grænse - måske fordi deres fremmedhed, med Brandes' term, er for stor, ikke bare for det brede publikum, men også for den mere afgrænsede del af befolkningen, der overhovedet kan finde på at læse en ældre skønlitterær bog. 


\begin{tabular}{|l|r|r|r|r|r|r|r|r|}
\hline & \multicolumn{1}{|l|}{ Bind } & \multicolumn{1}{l|}{$\%$} \\
\hline & $1967-77$ & $1978-88$ & $1989-99$ & I alt & $1967-77$ & $1978-88$ & $1989-99$ & I alt \\
\hline Romaner & 808 & 551 & 450 & 1809 & 70,5 & 69,3 & 68,7 & 69,7 \\
\hline Fortællinger & 27 & 20 & 23 & 70 & 2,4 & 2,5 & 3,5 & 2,7 \\
\hline Novellesamlinger & 128 & 78 & 57 & 263 & 11,2 & 9,8 & 8,7 & 10,1 \\
\hline Digte & 29 & 34 & 40 & 103 & 2,5 & 4,3 & 6,1 & 4,0 \\
\hline Dramatik & 132 & 95 & 63 & 290 & 11,5 & 11,9 & 9,6 & 11,2 \\
\hline Epik på vers & 17 & 13 & 20 & 50 & 1,5 & 1,6 & 3,1 & 1,9 \\
\hline Blandede skrifter & 5 & 4 & 2 & 11 & 0,4 & 0,5 & 0,3 & 0,4 \\
\hline I alt & 1146 & 795 & 655 & 2596 & 100,0 & 99,9 & 100,0 & 100,0 \\
\hline
\end{tabular}

Tabel 6: Klassikernes genrefordeling i elleveårsperioder og $i$ alt

\section{Klassikernes genrefordeling}

I europæisk sammenhæng kan skønlitteraturens tre storgenrer, epik, lyrik og dramatik, alle spores tilbage til oldtidens Grækenland. Dengang var litteratur primært beregnet på fremførelse for et publikum, men ser man på storgenrernes form, har lyrikken ændret sig forbavsende lidt siden, og trods mindre revolutioner undervejs er det egentlig først med de senere årtiers totalteater, at dramatikken for alvor har ændret karakter. Anderledes med epikken, der i oldtiden gerne var på vers, mens dens moderne hovedvarianter, romanen og novellen, er prosa. Disse genrer blev dog langt op i oplysningstiden betragtet som andenrangs, men siden 1800-tallet har romanen ubetinget været den dominerende skønlitterære genre. Romanerne udg $\varnothing$ r hovedparten af udgivelserne, de er stort set enerådende på bestsellerlisterne, og som det gentagne gange er blevet dokumenteret, dominerer de også bibliotekernes sk $\varnothing$ nlitterære indk $\varnothing b$ og udlån (17). I litteraturvidenskaben er dominansen dog mindre entydig, og det kunne vel tænkes, at genresammensætningen var væsentlig mere differentieret på klassikermarkedet end i samtidslitteraturen. Som det fremgår af Tabel 6 , er forskellene dog til at overse. (I tabellen er romaner defineret som prosatekster på mindst 100 sider, fortællinger er enkeltudgivne prosatekster på 49-99 sider, novellesamlinger er samlinger af flere prosatekster, og kategorien digte indbefatter prosadigte.)

Selv om romanen er den nyeste sk $\varnothing$ nlitterære genre, står den med en andel på ca. 70 \% uhyre stærkt på klassikermarkedet, men det er dog bemærkelsesværdigt, at den har tabt en anelse terræn undervejs. Dramatikken og novellesamlingerne har andele i omegnen af $10 \%$, med nedadgående tendens. Derimod har fortællingerne, digtene og epikken på vers haft markant procentuel fremgang, især fra 1989-99. Relativt mindst medvind er der for fortællingerne, mens de svært oversættelige genrer digte og versepik har fået mere end fordoblet deres andele og sågar har haft regulær fremgang i antal bind. Udviklingen for lyrikken kan også illustreres på denne måde: Fra 1967-77 var kun hvert 40. klassikerbind digte, fra 1978-88 var det ca. hvert 23. bind, og fra 1989-99 ca. hvert 16. bind. Det er temmelig overraskende, da man siden 1980'erne har set 'den smalle bog' og 'de smalle genrer' som udrydningstruede arter, men i hvert fald på klassikerniveau er det for begge de versbårne genrer gået over al forventning. Om denne styrkelse er en udmøntning af, at lyrikken der skrives ikke meget versepik i dag! - har stået meget stærkt i dansk litteratur siden ca. 1980 er ikke let af afgøre, men det forekommer plausibelt.

\section{Den dynamiske og den stabile klassiker}

Det normale for en bog er, at den får et kort, mere eller mindre intenst liv og derpå sygner hen, på bogmarkedet såvel som i læsernes bevidsthed. Nogle titler er nærmest d $\varnothing$ df $\varnothing$ dte og gør sig kun som 'lagersucceser', andre er mere sejlivede og genstand for betydelig interesse i en årrække, men for hovedparten af disse vil det også snart være slut. Og godt det samme, ellers kunne man jo ikke se klassikerne for bare bøger! Når en bog lever 
flere årtier er det opsigtsvækkende, og klarer den flere århundreder eller årtusinder er det lodret fantastisk. De første kaldes gerne moderne klassikere, de sidste bare klassikere, og præcis hvorfor de læses af generation efter generation, har det ikke været ambitionen at besvare her, men undersøgelsen dokumenterer, at de faktisk bliver læst, og den viser især noget om vores forbrug af udenlandske klassikere i den sidste tredjedel af det 20. århundrede.

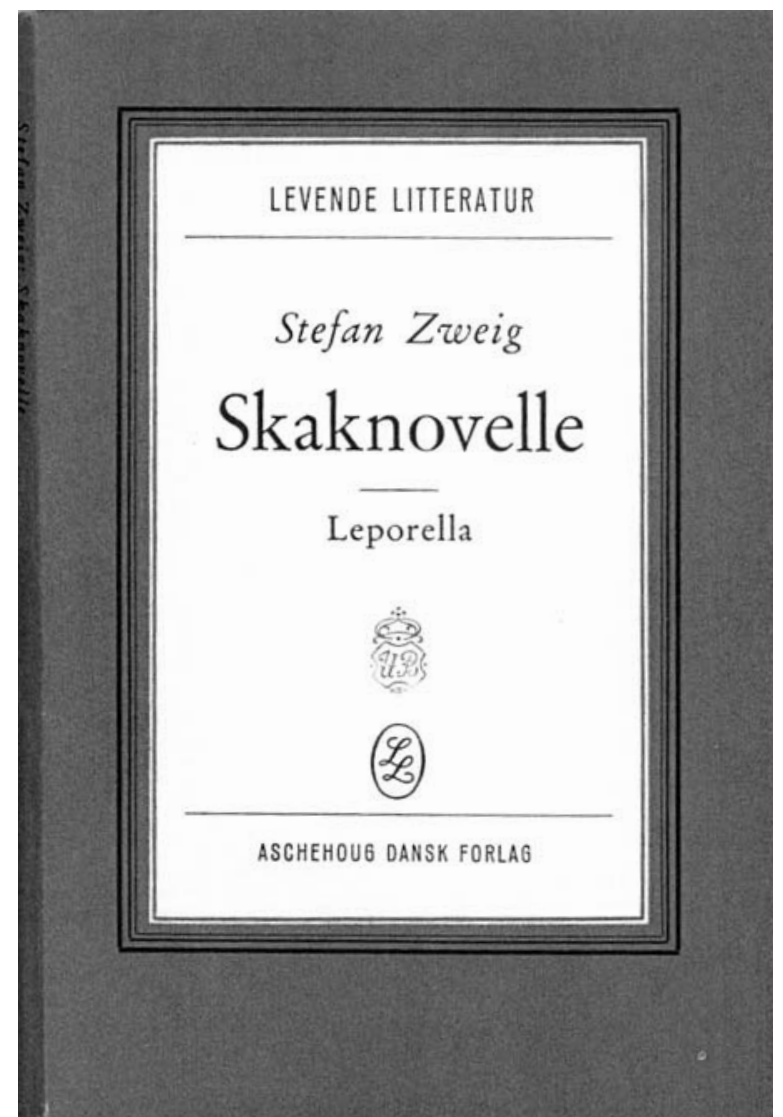

Skaknovelle/Leporella udkom på dansk i 17 oplag mellem 1948 og 1986, men herefter er ingen af den фstrigske forfatter Stefan Zweigs (1881-1941) skønlittercere bøger blevet udgivet på dansk. Her første danske udgave fra 1948.

Som det fremgik, var der en ganske betydelig udskiftning i forfatterpopulationen over et par årtier. Det betyder ikke, at Sofokles, Boccaccio og Goethe snart vil være fortid, rigtig fortid - det bliver de næppe foreløbig - men det betyder, at korpusset af klassikere ikke er en fast størrelse, men ændrer sig med tiden: "En klassiker er ikke noget man er, det er noget man bliver, det er noget, historien afg $\varnothing \mathrm{r}$. Og derefter atter historien: nok er en klassiker noget man bliver, men det er ikke noget man med sikkerhed forbliver" (18), som Erik Skyum-Nielsen har formuleret det. Og når de faktiske forfattere indtil videre stort set har været gemt bag et slør af tal, kan vi passende få nogle navne på bordet nu: Georges Simenon, Aksel Sandemose og Somerset Maugham udkom fra 196777 i henholdsvis 32, 28 og 24 bind, men fra 1989-99 var deres respektive bindantal faldet til tre, to og nul, og undersøgelsesperioden har også taget særdeles hårdt på bl.a. Aldous Huxley, Erich Maria Remarque, Stefan Zweig og Guy de Maupassant. Derimod blev Virginia Woolf slet ikke udgivet 1967-77, men fra 1989-99 er der udgivet ni bind, og Thomas Mann, Selma Lagerlöf, Anton Tjekhov og Joseph Conrad, der i den første elleveårsperiode kun kom $\mathrm{i}$ henholdsvis syv, tre, to og ét bind er $\mathrm{i}$ den sidste bugnet op til 20, 24 og to gange otte bind.

Imidlertid har voldsomme forskydninger som disse kun i begrænset omfang sat sig igennem i de analyserede kategorier, og i hvert fald når tallene har været mest stabile, må implikationen være, at hvis det er gået tilbage for en forfatter, er en anden af samme kategori gået frem. Fx er det gået tilbage for Tolstoj - og frem for Tjekhov. Men nogle signifikante bevægelser har der dog været, og hvis det vel ikke er overraskende, at kvinderne har haft fremgang, er der sikkert mange, som vil forbavses over, at kvindernes bedste periode er 198284 , at det er gået tilbage for amerikanerne, at Latinamerika ikke har haft større fremgang end tilfældet er, og at lyrikken og epikken på vers har klaret sig så godt.

Men hinsides de enkelte eksempler er pointen, at der er en udvikling - i kategorierne såvel som for den enkelte forfatter og titel - og at der rimeligvis er nogle årsager hertil. Det indebærer ikke, at tematisk substans og æstetisk udformning er uden betydning for, om en bog kan blive stående, men det er kvaliteter, der betragtes fra en bestemt kontekst - en bestemt tid, et bestemt rum - og i sidste instans vil det altid være eftertiden og den enkelte kultur, der afgør om et værk har klassikerstatus eller ej. 


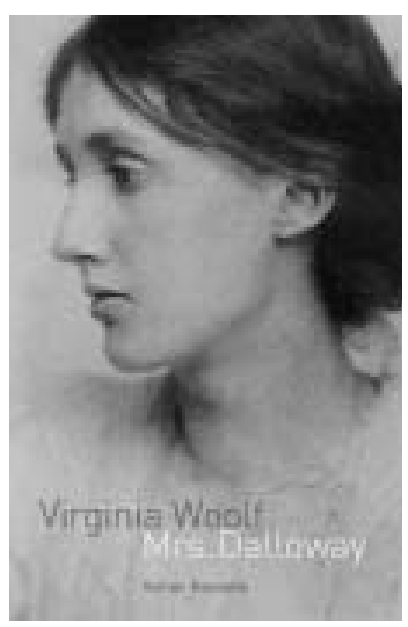

Den engelske forfatter Virginia Woolf (1882-1941) er først blevet udgivet stabilt på dansk siden 1982. Efter årtusindskiftet har forfatterskabet og iscer Mrs. Dalloway fået ny aktualitet via Michael Cunninghams roman Timerne og filmatiseringen af denne, The Hours. Her dansk paperbackudgave fra 2003.

\section{Biblioteket og klassikerne}

Har disse overvejelser relevans for bibliotekerne og deres formidling af klassikerne? Det mener jeg, de har. Klassikerne bør ikke betragtes som en ulæst gruppe af bøger, der kun skal stå på hylderne eller i magasinet som en bovlam legitimering af, at man bekymrer sig om kulturarven. Men det er heller ikke anbefalelsesværdigt at anskue klassikerne som et korpus af hæderkronede værker, der er hinsides diskussion. Klassikerne lever gennem den personlige anbefaling, men de står endnu stærkere, når de bliver udsat for en ny, kritisk læsning, hvor konklusionen er, at de stadig holder.

I bibliotekerne er det kutyme at tilstræbe den rette bog til den rette låner. For klassikernes vedkommende kunne en spidsformulering være: De rette klassikere til den rette tid! Her kan det naturligvis indvendes, at de mest levedygtige klassikere jo netop taler til enhver tid, men da vil forskellige tider typisk se delvis forskellige kvaliteter i værket, og i фvrigt vrimler litteraturhistorien jo med forfattere, der stort set er blevet ignoreret af samtiden, dernæst anerkendt af eftertiden som klassikere - og derpå måske igen er blevet glemt.
En forfatter som H. P. Lovecraft (1896-1937) fik kun en enkelt bog udgivet i sin levetid og blev ikke oversat til dansk, men især efter Stephen King pegede på ham som forbillede, voksede hans ry, og efter et enkelt bind på dansk fra 1978-88 er der udgivet syv bind fra 1989-99. Men siden 1995 har der igen været tavshed. Pointen er, at der er en relation mellem fortiden og nutiden, som pludselig gør denne forfatter interessant.

Karakteren af en sådan relation kan være meget forskelligartet. Det kan handle om temaer, der pludselig synes mere tidssvarende end før eller får os til at se den historiske udvikling i et nyt lys. Det kan være en bestemt skrivestil, som vinder frem blandt nye forfattere, og derfor bliver interessant, eller det kan være en filmatisering eller en dramatisering, som giver titlen aktualitet. Det kan også være en ny oversættelse, som får et ellers forældet værk til at virke appetitligt. Derfor er det vigtigt, hvilke klassikere bibliotekerne formidler på et givent tidspunkt, og det er afgørende hvordan de formidles. Måske er det ikke let, men formidlingen bør altid prøve at anskueligg øre, hvad der gør den enkelte klassiker spændende. For nutiden, for $o s$.

\section{Noter}

1. Ifølge Dansk Litteraturcenters www.litteraturnet.dk er Pontoppidan udgivet 11 gange i udlandet siden 1980 - og ikke udenfor Europa. Kun i ét land, Tyskland, er to forskellige værker blevet udgivet i perioden.

2. Da det er forfatterleksika, indgår anonyme værker ikke i undersøgelsen. Til gengæld er der, jvf. de meget store forfatterudvalg, ikke grund til at antage, at der uden for disse leksi$\mathrm{ka}$ findes ret mange forfattere med relevans for unders $\emptyset$ gelsen, hvad der underst $\varnothing t t e s$ af, at de få forfattere, som enkelte dagbladsanmeldere mente fejlagtigt var blevet overset eller ignoreret, kun i helt minimal grad havde påvirket resultaterne, ifald de var blevet inkluderet. I øvrigt skal jeg gøre opmærksom på, at jeg selv var skribent på Rosinantes værk, men ikke havde indflydelse på forfatterudvalget.

3. De vigtigste af disse er som følger: En bog er en alment læselig skrivelse (altså ikke blind- 
skrift) på over 48 sider, og det er Dansk BiblioteksCenters klassificeringer, der har afgjort, om en given bog er skønlitteratur (for voksne). Det skal her bemærkes, at DBC almindeligvis ikke klassificerer essays og eventyr som skønlitteratur. Novelle- og digtudvalg indgår i undersøgelsen, når mindst halvdelen af teksten har været udgivet på originalsproget senest 1945.

Forkortede eller på anden vis stærkt bearbejdede udgaver af originalteksten indgår ikke i unders $\varnothing$ gelsen, ligesom bidrag til antologier er udeladt, medmindre der er tale om et helt værk, fx et skuespil.

4. Her citeret efter: Erik Skyum-Nielsen: Den oversatte klassiker, s. 9.

5. En sådan metode ville for så vidt have været mere 'retfærdig', men for sammenligningsgrundlagets skyld var et fast korpus af klassikere mere velegnet.

6. Litteratursociologi, s. 15-16.

7. Heller ikke disse tal er offentligt tilgængelige, men ifølge Lisbeth Worsøe-Schmidt: Litteraturens situation og litteraturpolitikken, s. 57 faldt i hvert fald Gyldendals minimumsoplag for skønlitteratur ganske kraftigt fra 1970-71 til 1992-93 - og oplaget for billigbøger blev halveret.

8. Susan Faludi: Backlash. Dansk udgave: Tilbageslag.

9. I enkelte tilfælde er der tale om affattelsestidspunktet, ikke udgivelsesåret. Fx regnes Goethes Urfaust til 1700-tallet, selv om den først publiceres 1887. Mht. skuespil, hvor bogudgivelsen kan ligge før, samtidig med og efter opførslen på teatret, er originaludgaven konsekvent gjort synonym med det ældste af disse, ofte divergerende, årstal.

10. Sainte-Beuve: Kritikker og Portratter, s. 177.

11. Litteratursociologi, s. 129.

12. Georg Brandes: Om laesning, s. 15.
13. Ifald anonyme værker var inkluderet, havde middelalderen nok være lidt, men næppe markant bedre repræsenteret.

14. Verdens litteraturhistorie, bd. 1, s. 5 .

15. Verdens litteraturhistorie, bd. 1, s. 17.

16. De $\varnothing$ vrige europæiske nationer er repræsenteret som følger: Schweiz (51 bind), Østrig (43), Belgien (36), Irland (30), Finland (24), Oldtidens Rom (17), Island (16), Polen (10), det moderne Grækenland (3), og Holland (2).

17. Anne Lise Japsen: Biblioteket og den gode bo. Henrik Christoffersen m.fl.: Lånernes bogvalg. Claus Secher: Bibliotekernes og lånernes skønlitterare bogvalg.

18. Litteratursociologi, s. 133.

\section{Litteratur}

Brandes, Georg (1908). Om loesning. Gyldendal.

Christoffersen, Henrik m.fl. (1994). Lånernes bogvalg. Danmarks Biblioteksforening.

Faludi, Susan (1991). Backlash, Crown. Dansk udgave: Tilbageslag, Rosinante, 1993.

Forfatterleksikon. Udenlandsk litteratur (1999). Red. af Knud Michelsen. Rosinante.

Gads udenlandske forfatterleksikon (2001). Red. af Berit Højbjerg. Gad.

Japsen, Anne Lise (1992). Biblioteket og den gode bog. Gyldendal.

Litteratursociologi (1995). Red. af Erland MunchPetersen. Dansk BiblioteksCenter, 2. udg.

Sainte-Beuve, C.A. (1946). Kritikker og Portraetter. Athenæum.

Secher, Claus (2000). Bibliotekernes og lånernes skфnlittercere bogvalg. Biblioteksstyrelsen. 
Skyum-Nielsen, Erik (1997). Den oversatte klassiker. Det Kongelige Bibliotek: Museum Tusculanum.

Verdens litteraturhistorie (1971). Bd. 1. Redigeret af F. J. Billeskov Jansen, Hakon Stangerup og P. H. Traustedt. Politiken.

Verdens litteraturhistorie (1985). Bd. 1. Redigeret af Hans Hertel. Gyldendal, 1985.

Worsøe-Schmidt, Lisbeth (1994). Litteraturens situation og litteraturpolitikken. Klim. 